\title{
O processo de Jesus: João relendo o relato sinóptico
}

\author{
Jesus' Trial: \\ John Rereading the Synoptic Narrative
}

Johan Konings

\section{Resumo}

$\mathrm{O}$ artigo oferece uma abordagem exploratória da narrativa joanina do processo de Jesus, sobre o pano de fundo dos relatos sinópticos, como experiência metodológica para articular o método sincrônico de leitura ( $1^{\mathrm{a}}$ parte $)$ com a análise diacrônica do texto ( $2^{\mathrm{a}}$ parte). João segue substancialmente os sinópticos, porém, acentua os dois círculos concêntricos diante dos quais os cristãos se encontram em processo, "os judeus" e "o mundo". Em vista do círculo interior, João insere o interrogatório perante Anás, que atualiza o texto para a situação da comunidade que deve testemunhar a respeito dos discípulos e do ensinamento. Em vista do círculo do mundo, João amplia o interrogatório perante Pilatos, para mostrar em que consiste o verdadeiro domínio daquele que está sendo julgado pela suposta pretensão de ser rei dos judeus: o domínio da "verdade" que ele testemunha. Também os outros traços que diversificam a narrativa joanina da sinóptica correspondem à intenção própria do autor e ao efeito que o texto quer produzir no leitor. A pragmática do texto joanino aponta para uma situação em que o leitor/ouvinte, identificando-se com o discipulado, é instado a dar testemunho da "verdade".

Palavras-chave: Evangelho de João. Processo de Jesus. João e sinópticos. Leitura narrativa. Testemunho da Verdade. 


\begin{abstract}
This paper offers an exploratory approach of the Johannine narrative of Jesus' Arrest and Trial against the background of the synoptic narratives. It aims to be an experiment in articulating synchronic reading (1st. part) and diachronic text analysis (2nd. part). John follows substantially the Synoptic narratives, but highlights the two concentric circles of adversaries with whom the Christians are in process, "the Jews" and "the world". In regard to the inner circle, John inserts in the synoptic frame the interrogatory before Annas, adapting the text in view of the situation of the community that must testify about Jesus' teaching and disciples. In regard to the circle of the world, he amplifies the interrogatory before Pilatus in order to show which is the true realm of Jesus, falsely accused as King of the Jews: the dominion of the "truth" he testifies. Also the other differences between the Johannine and the Synoptic narratives are in line with the Author's intent and the effect induced in the reader. The pragmatism of the Johannine text suggests identification of the reader with the disciples, being invited to give a testimony of the "truth".
\end{abstract}

Keywords: John's Gospel. Trial of Jesus. John and Synoptics. Narrative Reading. Testimony of Truth.

\title{
Introdução
}

O presente estudo exploratório tem por objeto a peculiaridade da narrativa joanina do processo de Jesus, sobre o pano de fundo dos relatos sinópticos ${ }^{1}$. Pretende também testar um modo de articular o método sincrônico de leitura com a análise diacrônica do texto. De fato, se consideramos que o Quarto Evangelho não é um "primeiro anúncio", mas antes, uma "ruminação", e que o leitor implícito já conhece substancialmente a tradição do processo de Jesus, os textos sinópticos parecem uma amostra confiável da tradição que "João" relê com o leitor ${ }^{2}$.

\footnotetext{
${ }^{1}$ Apresentamos os textos em tradução literal, baseada em ALAND, K. Synopsis quattuor Evangeliorum: locis parallelis evangeliorum apocryphorum et patrum adhibitis. 9. erneut revid. Aufl. Stuttgart: Württembergische Bibelanstalt, 1976, e KONINGS, J. Sinopse dos evangelhos de Mateus, Marcos e Lucas e da "Fonte Q". São Paulo: Loyola, 2005.

${ }^{2}$ Cf. DAUER, A. Die Passionsgeschichte im Johannesevangelium: Eine traditionsgeschicht-
} 


\section{Um olhar sincrônico}

O processo de Jesus faz parte da segunda parte do Quarto Evangelho, comumente chamada "o Livro da Glória" (Jo 13-20). Este descreve a "consumação" $(19,30)$ da obra de Jesus na sua "hora", diversas vezes anunciada $(2,4 ; 12,23.27$; cf. 7,$30 ; 8,20)$ : a hora da glorificação de Jesus, e de Deus nele (12,31-33). O Livro da Glória inicia com a chegada da "hora" $(13,1)$ e da glorificação (13,31-32), temas que alimentam o capítulo central, Jo 17, a oração do Senhor glorioso, que exprime o sentido último de sua obra: "que o amor com que me amaste esteja neles e eu também esteja neles" $(17,26)$.

Convém ler o texto de 18,1-19,16a à luz deste texto. O arco entre o anúncio da chegada da "hora", em 13,1, e sua menção quando da consumação, em 19,27 ("aquela hora"), evidencia que os capítulos 13-17 constituem o pano de fundo teológico para a compreensão adequada de Jo 18-20, consumação da obra de Jesus e manifestação da "glória" de Jesus e do Pai. Outro indício dessa coerência é a presença das mesmas dramatis figurae (Pedro, Judas e o Discípulo Amado) em 13,1-30 e 18,1-27. Jo 18-20 narra a plena realização do amor que Jesus leva à tona em 13-17 (pelo gesto simbólico do lava-pés, 13,1-20; pelo novo mandamento, 13,34-35, explicitado na alegoria da vinha, 15,1-17; e pela conclusão da oração em 17,26). As palavras de Jo 13-17 enunciam o amor de Jesus, os capítulos 18-20 mostram sua realização efetiva: a ação que segue e confirma a palavra. Jesus ama "não só em palavra e língua, mas em ação e verdade" (1Jo 3,18).

Os capítulos 18-20 subdividem-se em dois momentos, a paixão e morte (cap. 18-19) e a ressurreição (cap. 20), "cruz e coroa" da mesma realidade, a glória de Cristo e do Pai nele. Nos capítulos 18-19 distinguem-se três sequências: a prisão de Jesus e seu processo perante as autoridades judaicas (18,1-27); sua entrega a Pilatos e o processo perante a autoridade romana $(18,28-19,16 a)$; e sua execução e morte na cruz, seguida do sepultamento

liche und theologische Untersuchung zu Joh. 18,1-19,30. München: Kösel, 1972; SABBE, M. "The Arrest of Jesus in Jn 18,1-11 and Its Relation to the Synoptic Gospels: a Critical Evaluation of A. Dauers Hypothesis". In: SABBE, M. Studia Neotestamentica: Collected Essays. Leuven: Peeters, 1991, pp. 355-388; ZUMSTEIN, J. “Der Prozess Jesu vor Pilatus. Ein Beispiel Johanneischer Eschatologie”. In: ZUMSTEIN, J. Kreative Erinnerung: Relecture und Auslegung im Johannesevangelium. Zürich: Theologischer Verlag, 2004, pp. 253-273. Também BEUTLER, J. Evangelho segundo João: comentário. São Paulo: Loyola, 2015; KONINGS, J. Evangelho segundo João: amor e fidelidade. 2. ed. São Paulo: Loyola, 2005 (ad locum). Os grandes comentários de Schnackenburg e Brown são reticentes na questão João x sinópticos. 
$(19,16 b-42)$. Limitamos nosso estudo às duas primeiras sequências do relato da paixão e morte - o "processo" -, porque correspondem aos dois círculos da resistência contra Jesus: o círculo interior, constituído por aqueles que João chama "os judeus"; e o círculo abrangente, que ele chama de "o mundo", aqui representado pelo Império romano ${ }^{4}$. Delimitamos, portanto, o processo como microrrelato dentro do relato maior da Paixão.

A linha narrativa deste microrrelato é a seguinte: depois da ceia, Jesus se dirige ao jardim das Oliveiras com os discípulos, menos Judas, que leva a coorte romana e os guardas dos sumos sacerdotes para, à traição, prenderem Jesus. Antes, porém, que Judas execute seu gesto, Jesus se apresenta por iniciativa própria e manda, soberanamente, que os guardas liberem os discípulos. Depois, levam Jesus aos sumos sacerdotes, primeiro a Anás, que o interroga; e depois, a Caifás, mencionado só de passagem. O interrogatório é emoldurado pela negação de Jesus por Pedro.

Terminado o interrogatório, as autoridades judaicas entregam Jesus ao poder romano, representado por Pôncio Pilatos. O interrogatório de Pilatos, no pretório, é alternado com interlocuções com os “judeus”, que permanecem fora. Criam-se, assim, sete cenas, tendo como centro o escárnio de Jesus como "rei dos judeus". Os judeus exigem para Jesus a pena capital que eles mesmos não podem aplicar: a crucificação. Pilatos procura inocentar Jesus, querendo se livrar do caso. Ele propõe uma anistia por ocasião da festa da Páscoa, mas os "judeus" pedem a anistia para Barrabás e ameaçam denunciar Pilatos ao Imperador. Pilatos, então, lhes entrega Jesus para que o crucifiquem.

Os dois processos são unidos pelo tema do "entregar" (com seu duplo sentido de trair e de remeter). O verbo paradídomi é repetido sete vezes (das 15 ocorrências em João). Na primeira sequência, o entregar, efetivado por Judas $(18,2.5)$, é revezado pela negação de Pedro, que culmina no canto do

\footnotetext{
${ }^{3}$ Judeus: 1) genericamente, o povo judeu em geral; 2) os "judeus" (marcados com aspas em BEUTLER, Evangelho), a saber, os adversários de Jesus entre os judeus, principalmente, as lideranças.

${ }^{4}$ Como o termo "judeus", também o termo "mundo" tem dois sentidos: 1) o mundo da criação e da humanidade visto como destinatária do amor de Deus; 2) o mundo como âmbito inimigo, fechado à proposta de Deus em Jesus. No sentido negativo, os "judeus" podem ser considerados como o círculo interior e o "mundo" como o círculo abrangente dos que recusam a luz, como aparece em Jo 1,10-11: o mundo... os seus...). Cf. KONINGS, Evangelho, p. 37.

${ }^{5}$ Cf. JANSSENS DE VAREBEKE, A. "La structure des scènes du récit de la Passion en Joh., 18-19. Recherches sur les procédés de composition et de rédaction du Quatrième Évangile". Ephemerides Theologicae Lovanienses 38 (1962), pp. 504-522; retomado, com modificações, em BEUTLER, Evangelho, p. 405-407. Cf. também KONINGS, Evangelho, p. 326.
} 
galo $(18,27)$. Na segunda sequência são as autoridades judaicas que entregam Jesus a Pilatos. O tema ganha sua intensidade maior quando Jesus diz: "Quem me entregou a ti tem pecado maior" $(19,11)$. Finalmente, aparece na conclusão do processo, quando não são mais os judeus que entregam Jesus a Pilatos, mas Pilatos que o entrega a eles $(19,16)$, levando assim o microrrelato a seu desfecho pela inversão do movimento. Mas esse desfecho é provisório: o verbo $p a-$ radídonai reaparecerá na próxima sequência, a crucificação, quando ninguém mais entrega Jesus, mas ele mesmo entrega o espírito ao Pai e - segundo uma exegese bastante plausível - também aos fiéis.

No microrrelato encontramos duas janelas de diálogo, emolduradas pela narrativa e com forte efeito pragmático no leitor implícito. A primeira é a indagação de Anás a respeito dos "discípulos e do ensinamento" (18,19-21). O leitor se pergunta: quem trai, entrega ou nega Jesus e quem está com ele? A segunda janela é a indagação de Pilatos a respeito do reino ou domínio de Jesus, o "reino da verdade" (18,33-38), propondo ao discípulo e ao leitor a pergunta se ele "é da verdade".

Entre os discípulos - os mesmos que figuraram no lava-pés - dá-se uma separação de caminhos. Judas será o filho da perdição (cf. 17,12). Pedro, representante dos que acompanharam Jesus, esvaece na negação. O Discípulo Amado, porém, que só aparece na segunda parte do evangelho $(13,23)$, segue realmente seu Mestre até o fim do caminho ${ }^{6}$. Depois de introduzir Pedro no palácio de Anás, ele fica no segundo plano durante o processo $(18,15-16)$, mas, na hora da crucificação $(19,26)$, ele estará onde está Jesus (cf. 12,26) e será a testemunha por excelência $(19,35)$.

O protagonista é Jesus, sempre soberano, ciente da situação ${ }^{7}$ e fiel à sua missão, tanto perante Anás como perante Pilatos, que contracenam com Jesus como agentes dos respectivos círculos de oposição ${ }^{8}$. Diante de Pilatos, Jesus afirma seu domínio, porém não na qualidade de "rei dos judeus" $(18,37)$. O antagonista principal, contudo, não são os acusadores humanos de Jesus, e nem o traidor, instrumentalizado pelo diábolos (cf. 13,2), que é o articulador da entrega de Jesus à autoridade do "mundo" e o verdadeiro culpado (19,11b).

João não nos faz entrar na percepção pessoal dos personagens, nem menciona a compunção de Pedro; e, se aponta brevemente o medo de Pilatos diante da intransigência dos judeus, é porque este elemento faz parte da intriga (a

\footnotetext{
${ }^{6} \mathrm{Cf}$. infra, nota 19.

${ }^{7}$ Outra semelhança com o lava-pés.

${ }^{8}$ Cf. supra, nota 4.
} 
chantagem). A focalização preponderantemente externa corresponde à função do narrador como testemunha diante da comunidade.

As duas sequências situam-se, respectivamente, na noite e na manhã do dia de preparação da Páscoa, de acordo com a cronologia joanina. A atmosfera noturna já tinha sido antecipada pelo narrador quando Judas saiu da ceia: "Era noite" $(13,30)$. Mas a saída de Judas aciona também o "agora" da "glorificação" (13,31-32) ${ }^{9}$. Assim, a detenção de Jesus, na hora das trevas, é iluminada por sua manifestação soberana como "Eu sou" (18,5.8; cf. 8,28). A luz resplandece nas trevas, que "não a conseguiram subjugar" $(1,5)$. No entanto, o discípulo-chefe, Pedro, parece sucumbir às trevas (cf. 12,35), longe do testemunho de Jesus e perto do dos soldados em torno do fogo de brasas $(18,18)$.

O interrogatório perante Pilatos se dá, como nos sinópticos, de manhã cedo. Diferente de Marcos ${ }^{10}$, João não pontua o decorrer das horas. Entretanto, evidencia que o processo se dá no momento que precede a refeição pascal, razão por que os judeus não entram no pretório $(18,28)$. E, coerentemente, menciona que Jesus é condenado na hora em que os cordeiros pascais são levados à imolação $(19,14)$, o que reforça a associação entre Jesus e o cordeiro pascal $(19,36$; cf. 1,29).

João narra o processo de Jesus do ponto de vista do discipulado em situação de processo e perseguição. Os discursos de despedida já revelaram este ponto de vista $(15,18-26$, a inimizade do mundo e a inocência de Jesus; 16,711, o Paráclito como defensor-acusador no processo). O autor se identifica com o grupo dos perseguidos e traz à consciência a necessidade de escolher entre a assimilação ao mundo e o testemunho de Jesus, que testemunha a verdade ("ser da verdade", 18,37).

\section{A redação joanina e seu substrato sinóptico}

Ao comparar o texto joanino com os relatos sinópticos, vemos que as semelhanças são muitas e as diferenças, facilmente explicáveis no quadro da redação joanina ${ }^{11}$.

\footnotetext{
${ }^{9}$ Cf. KONINGS, Evangelho..., p. 269.

${ }^{10} \mathrm{Mc} 15,25.33 .34$.

${ }^{11} \mathrm{Na}$ tradução literal apresentada a seguir, as semelhanças verbais com pelo menos um dos sinópticos são apontadas por sublinha ininterrupta; as semelhanças meramente temáticas, por sublinha pontilhada. Não podemos aqui explicar detalhadamente todas as semelhanças e diferenças, mas a apresentação gráfica fala por si mesma. Onde não aparecem sublinhas mostrando as semelhanças, presume-se presença forte da redação joanina.
} 


\subsection{O processo perante "os judeus"}

O versículo inicial, 18,1, revela forte proximidade dos sinópticos:

Jo 18,1 Tendo dito isso, Jesus saiu com seus discípulos para além da torrente do Cedron, onde havia um jardim, para o qual entrou ele e seus discípulos. Mc $14,26 \mathrm{E}$, tendo cantado o hino, saíram para o Monte das Oliveiras. (...) ${ }^{32}$ E vão a um terreno de nome Getsêmani, e ele diz aos seus discípulos... Mt 26,30 E, tendo cantado o hino, saíram para o Monte das Oliveiras. (...) ${ }^{36}$ Então, Jesus vai com eles a um terreno chamado Getsêmani e diz aos discípulos...

Lc ${ }^{22,39} \mathrm{E}$, tendo saído, foi, como de costume, para o Monte das Oliveiras. Também os discípulos o acompanharam.

Detalhando: 1) "tendo dito isso": cf. Mc 14,26\|Mt (tendo cantado, no fim da ceia); 2) "saiu" (exêlthen): cf. Mc 14,26\|Mt; 3) "discípulos": cf. Mc 14,30\|Mt; Lc 22,39; 4) "jardim": refere-se ao Getsêmani, "jardim das Oliveiras", em Mc 14,32\|Mt 26,36; João tem certa preferência pelo termo "jardim" (no Novo Testamento: Lc 13,39; Jo 18,1.26; 19,41; cf. "jardineiro", só em Jo 20,15); 5) "entrou" (eisêlthen) corresponde a "saiu" (exêlthen cf. supra) e a érkhontai/érkhetai em Mc 14,32\|Mt 26,36. Estritamente próprio de João é somente a expressão "além da torrente do Cedron", que lembra a saída de

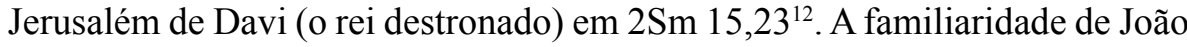
com Jerusalém é conhecida, enquanto nos sinópticos o ponto de vista geográfico é galileu.

O versículo seguinte, 18,2, supõe a informação de que Jesus pernoitava no monte das Oliveiras. A descrição sinóptica de Judas, "o entregando-o" (cf. v. 5b), é enriquecida com a explicação de que Judas conhecia o lugar, porque Jesus muitas vezes esteve aí com seus discípulos. Isso corresponde ao que escrevem Mt 21,17 e Lc 21,37, explicitando Mc 11,11b.19: Jesus saía da cidade para pernoitar em Betânia ou no monte das Oliveiras (Lc), onde pernoitavam os peregrinos que não tinham como se hospedar em Jerusalém.

Jo 18,2 Sabia também Judas, o entregando-o, o lugar, porque muitas vezes Jesus se reuniu ali com seus discípulos.

${ }^{12}$ Cf. LÉON-DUFOUR, X. Leitura do Evangelho segundo João (IV). São Paulo: Loyola, 1998, p. 25 , nota 25 . 
Jo 18,3 mostra a mesma tendência de Lc 22,47 de pôr Judas à cabeça da turba.

Jo 18,3 Judas, pois, tendo levado a coorte e súditos dos sumos sacerdotes e dos fariseus, vem aí com fachos e lâmpadas e armas.

${ }^{\mathrm{Mc}}{ }^{14,43} \mathrm{E}$ logo, ele ainda a falar, chega Judas, um dos Doze, e com ele uma turba com espadas e paus, da parte dos sumos sacerdotes e dos escribas e dos anciãos.

Mt 26,47 E ele ainda a falar, veio Judas, um dos Doze, e com ele uma turba numerosa com espadas e paus, da parte dos sumos sacerdotes e dos anciãos do povo.

Lc 22,47 Ele ainda a falar, eis uma turba, e o chamado $\underline{\text { Judas, }}$ um dos Doze, os precedia.

João acrescenta aos súditos dos sumos sacerdotes e dos anciãos a coorte romana (speira). No lugar dos "escribas e anciãos" (Mc) ou "anciãos do povo" (Mt), coloca os fariseus, que no tempo da redação tinham a hegemonia no judaísmo (cf. 1,24). As "armas" correspondem às espadas e paus de Mc 14,43\|Mt 26,47. Os "fachos e lâmpadas", próprios de João, são sugeridos pelo cenário noturno.

Nos vv. 4-5, a descrição corresponde à tendência joanina de acentuar a soberania de Jesus no dom de sua vida (cf. 10,18). Em vez de ser vítima do complô para prendê-lo, Jesus mesmo sai ao encontro dos que vêm aprisioná-lo e se apresenta com a fórmula de manifestação "Eu sou", que se repetirá uma segunda e uma terceira vez $(18,5.6 .8)^{13}$.

${ }^{4}$ Jesus, pois, sabendo tudo que estava por vir sobre ele, saiu e disse-lhes: A quem buscais? ${ }^{\text {sab }}$ Responderam-lhe: A Jesus, o nazareno. Diz-lhes: Eu sou.

Foi apontada a semelhança com a pergunta de Jesus aos primeiros discípulos: "O que buscais?" $(1,38)$. Pode-se dizer que aquilo que era indefinido no início ("o quê"), tomou corpo na narrativa da obra de Jesus, de modo que agora a pergunta se refere a alguém: "A quem buscais?"14, e este alguém declara soberanamente: "Eu sou". Isto se dirige não apenas aos soldados e aos

${ }^{13}$ Também na diatribe do cap. 8 esta fórmula é repetida três vezes (Jo 8,24.28.58). No processo, ela contrasta com a tríplice negação de Pedro e com a tríplice afirmação da inocência de Jesus por Pilatos.

${ }^{14}$ Cf. também a pergunta a Maria Madalena, Jo 20,15. 
guardas, mas ao leitor implícito, que, no evangelho inteiro, é solidário com os discípulos.

Depois da automanifestação e autoentrega de Jesus, o beijo combinado por Judas para traí-lo não tem mais sentido: no v. $5 \mathrm{c}$, Judas, o entregando-o (ho paradidoùs autón, cf. Mc 14,44\|Mt 28,8), está aí, mas sem função, e é a última vez que é mencionado. Sai de cena.

Jo 18,5c Estava também Judas, o entregando-o, com eles.

Mc 14,44 $\underline{\mathrm{O} \text { entregando-o }}$ lhes tinha dado uma senha, dizendo: É aquele que eu beijar: prendei-o e conduzi-o com segurança! ${ }^{45} \mathrm{E}$ indo, logo se aproximando dele, diz: Rabi! E beijou-o.

${ }^{\mathrm{Mt}} 26,48 \mathrm{O}$ entregando-o lhes deu um sinal, dizendo: É aquele que eu beijar, prendei-o! ${ }^{49}$ E logo se aproximando de Jesus, disse: Salve, Rabi! E beijou-o.

Lc 22,47b (...) e chegou perto de Jesus para beijá-lo.

A autoapresentação do Jesus soberano continua nos vv. 6-9:

Jo 18,6 Quando, pois, lhes disse: Eu sou, foram-se para trás e caíram no chão. ${ }^{7}$ De novo, pois, interrogou-os: A quem buscais? Eles disseram: A Jesus, o nazareno. ${ }^{8}$ Respondeu Jesus: Disse-vos que eu sou. Se, pois, a mim buscais, deixai estes partirem. ${ }^{9}$ Para que fosse cumprida a palavra que ele disse (que): Os que me deste, não perdi dentre eles nenhum.

Aqui é palpável o estilo da redação joanina: o "pois" expletivo; o "para que" introduzindo o cumprimento da palavra de Jesus ${ }^{15}$; a maneira depreciativa de chamar a Jesus de "nazareno" (cf. 1,45; 18,5.7; 19,19); o buscar Jesus $(z \bar{e} t e \hat{n})^{16}$, repetido pela terceira vez; e, sobretudo, a acentuação da soberania de Jesus, mediante a três vezes repetida fórmula de manifestação "eu sou" (cf. supra), que produz o efeito do temor: os guardas recuam e caem por terra. Em João, os guardas não prendem de imediato Jesus para conduzi-lo seguro (Mc 14,44), mas Jesus lhes ordena liberar os discípulos. Estes não precisam fugir, como nos sinópticos, mas recebem de Jesus como que a permissão de se retirar ${ }^{17}$. João vê nisso a confirmação e sentido pleno da palavra de Jesus a

\footnotetext{
${ }^{15}$ A fórmula "para que se cumprisse" é frequente em Mt e Jo, mas só João a aplica à palavra de Jesus $(18,9.32)$.

${ }^{16}$ zèteîn: Jo $34 \mathrm{x}$

${ }^{17}$ Cf. BEUTLER, Evangelho..., pp. 411-412.
} 
respeito de sua missão de não deixar nada ou ninguém se perder $(6,39 ; 17,12$; aqui é a terceira vez). Segundo a pragmática textual, isso implica também o leitor, que é solidário com os discípulos.

Nos versículos seguintes, 10-11a, João reformula o episódio sinóptico da espada:

Jo 18,10 Simão Pedro, pois, tendo uma espada, puxou-a e feriu o servo do sumo sacerdote e cortou a ponta da orelha direita dele. O nome do servo era Malco. ${ }^{11 a}$ Disse, pois, Jesus a Pedro: Põe a espada na bainha.

${ }^{\mathrm{Mc}}{ }^{14,47} \mathrm{Um}$ [algum] dos presentes, tendo puxado a espada, feriu o servo do sumo sacerdote e tirou a ponta da orelha dele.

${ }^{\mathrm{Mt} 26,51} \mathrm{E}$ eis, um dos com Jesus estendeu a mão, puxou a espada e ferindo $\underline{\mathrm{o}}$

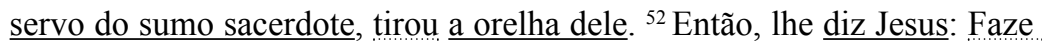
voltar a tua espada ao seu lugar!

${ }^{\text {Lc } 22,49}$ Vendo o que ia acontecer, os que estavam com ele disseram: Senhor, será que atacamos com a espada? ${ }^{50} \mathrm{E}$ um deles feriu o servo do sumo $\underline{\text { sacerdote e tirou a orelha direita dele. }}{ }^{51}$ Respondendo, porém, $\underline{\text { Jesus disse: }}$ Deixai, até aqui!

Como em outros casos, João dá um nome aos atores anônimos ${ }^{18}$ : quem fere a orelha do servo do sumo sacerdote é Simão Pedro, e o atingido se chama Malco. Esta identificação será lembrada no reconhecimento de Pedro no pátio do sumo sacerdote $(18,26)$.

O v. 11b lembra a agonia de Jesus, que em João não vem narrada como tal, mas foi antecipada em 12,27s. Em 18,11b, aparece uma reminiscência sinóptica: a taça.

Jo $18,11 \mathrm{~b}$ A taça que me deu o Pai, não a beberia?

Mc 14,36 E dizia: Abbá, Pai, tudo é possível para ti, afasta de mim esta taça, mas não o que eu quero, mas o que tu \{queres\}. ( $\|$ Mt 26,39b\|Lc 22,42, sem diferenças substanciais).

Também a efetivação da prisão (v. 12-14) lembra os sinópticos:

Jo $18,12 \mathrm{~A}$ coorte, pois, e o comandante e os súditos dos judeus levaram Jesus consigo e ligaram-no, ${ }^{13} \mathrm{e}$ conduziram-no, primeiro, a Anás, pois era sogro de Caifás, que era sumo sacerdote daquele ano.

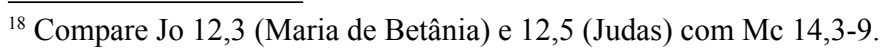


Mc 14,45 Eles, porém, lançaram as mãos nele e o prenderam. (...) ${ }^{53} \mathrm{E}$ conduziram Jesus ao sumo sacerdote, e juntaram-se todos os sumos sacerdotes e os anciãos e os escribas.

${ }^{\mathrm{Mt} 26,50 \mathrm{~b}}$ Então eles avançaram, lançaram as mãos sobre Jesus e o prenderam. (...) ${ }^{57}$ Eles, tendo preso Jesus, conduziram $\{$-no $\}$ ao sumo sacerdote Caifás, onde estavam os escribas e os anciãos.

Lc 22,54 Tendo-o aprisionado, porém, conduziram-no e o introduziram na casa do sumo sacerdote.

João não desenvolve o interrogatório de Jesus perante Caifás, apenas mencionado de passagem $(19,24)$. Substitui-o pelo interrogatório perante Anás, utilizando, porém, algumas reminiscências do interrogatório de Caifás. Anás é identificado por referência a seu genro Caifás, conhecido da tradição sinóptica e lembrado aqui por sua profecia involuntária em Jo 11,49-50 (que logo irá se cumprir).

Jo 18,14 Era Caifás que tinha aconselhado aos judeus (que): Convém que um homem morra pelo povo.

A chegada ao palácio do sumo sacerdote (v. 15) é narrada de modo conciso, como nos sinópticos, mas, segundo João, além de Pedro segue também o "outro discípulo", conhecido da casa, o que explica a admissão de Pedro no palácio do sumo sacerdote (que os sinópticos não explicam) ${ }^{19}$.

Jo 18,15 Seguia Jesus Simão Pedro e um outro discípulo. Esse discípulo era conhecido do sumo sacerdote e entrou com Jesus no pátio do sumo sacerdote.

${ }^{M c} 14,54$ E Pedro seguiu-o, de longe, até dentro do pátio do sumo sacerdote. Mt 26,58 Pedro, porém, seguia-o de longe, até o pátio do sumo sacerdote, $\mathrm{e}$ tendo entrado dentro...

Lc 22,54c Pedro, porém, seguia de longe.

Diferentemente dos sinópticos, a primeira negação de Pedro (v. 16-17) se

\footnotetext{
${ }^{19}$ Sobre a identificação do "outro discípulo", veja COLSON, J. L'énigme do disciple que Jésus aimait. Paris: Beauchesne, 1969, p. 97. Posição crítica: NEIRYNCK, F. “"The Other Disciple' in Jn 18,15-16”. Ephemerides Theologicae Lovanienses 51 (1975), pp. 113-141. Se o exame histórico-literário não fornece certeza, a leitura narrativa sugere a identificação com o Discípulo Amado, que também em 20,2.3.4.8 é chamado "o outro discípulo" ao lado de Pedro. Neste sentido: ZUMSTEIN, J. L'évangile selon saint Jean (13-21). Genéve: Labor et fides, 2007, p. 209, nota 12.
} 
dá logo na entrada, diante da menina que abre a porta (paidiskē hē thyrōrós), cena antecipada de Mc 14,69s. IMt 26,66s. ILc 22,56s. (cf. adiante).

Jo 18,16 Pedro, porém, estava junto à porta, fora. Saiu, pois, o outro discípulo, conhecido do sumo sacerdote, e falou à porteira, e conduziu Pedro para dentro. ${ }^{17}$ Diz, pois, a criada, a porteira, a Pedro: Não és também tu dentre os discípulos daquele homem? Disse ele: Não sou.

Depois (v. 18), como nos sinópticos, Pedro se instala no meio dos "súditos" (hyperétai) do sumo sacerdote, junto do fogo, para se aquecer.

Jo 18,18 Estavam aí os servos e os súditos, tendo feito um fogo de carvão, porque era inverno, e aqueciam-se; Pedro estava com eles e aquecia-se. Mc 14,54 (...) e estava sentado com os súditos e aquecendo-se junto do fogo. Mt 26,58 (...) sentou-se com os súditos para ver o fim. Lc 22,55 Tendo acendido um fogo no meio do pátio e sentados junto, Pedro sentou-se no meio deles.

A substituição do interrogatório de Caifás por aquele de Anás (v. 19-23) tem índole atualizadora. Enquanto Caifás interroga Jesus sobre sua messianidade (Mc 14,61 par.), Anás pergunta sobre seus discípulos e seu ensinamento. Para os leitores na comunidade joanina no fim do século I, a messianidade de Jesus não é novidade; atual, porém, é a questão dos discípulos e do ensinamento. Quando Anás levanta esta pergunta, Jesus o remete aos discípulos; mas - fato irônico -, o discípulo-chefe, depois de negar conhecer Jesus, está escondido no grupo dos adversários. Em tempo de perseguição, Pedro representa o exemplo a não seguir; e o leitor se pergunta: "E eu?"

O interrogatório de Anás é próprio de João, mas logo aparece uma reminiscência dos sinópticos:

Jo $18,19 \mathrm{O}$ sumo sacerdote, pois, interrogou Jesus a respeito de seus discípulos e a respeito de seu ensinamento. ${ }^{20}$ Respondeu-lhe Jesus: Eu falei no claro ao mundo, eu sempre ensinei na sinagoga e no templo, onde todos os judeus se reúnem, e no escondido não falei nada. ${ }^{21}$ Que me interrogas? Interroga os que ouviram o que lhes falei; eis, estes sabem o que eu disse. Mc ${ }^{14,49}$ Diariamente eu estava convosco, no templo, ensinando, e não me prendestes.

Mt 26,55b (...) Diariamente eu me sentava convosco, no templo, ensinando, e não me prendestes. 
Lc 22,53 Diariamente eu estando convosco, no templo, não estendestes as mãos para mim. (Cf. também Lc 19,47).

\author{
A bofetada (v. 22) lembra a cena final do interrogatório sinóptico perante \\ Caifás: \\ Jo 18,22 Tendo ele dito isto, um que estava com os súditos deu uma bofetada \\ em Jesus, dizendo: Respondes assim ao sumo sacerdote? \\ Mc 14,65 E alguns começaram a cuspir nele e a vendar-lhe o rosto e a \\ golpeá-lo... \\ Mt 26,67 Então cuspiram no seu rosto e golpearam-no, eles o esbofetearam... \\ ${ }^{\mathrm{Lc}}{ }^{22,63} \mathrm{E}$ os varões que o detinham escarneciam dele espancando-o.
}

Em vez das provocações para fazer Jesus profetizar (Mc 14,65b par.), João introduz uma resposta soberana de Jesus (v. 23), que desafia Anás a apresentar uma acusação válida. A expressão martyreîn peri ("testemunhar a respeito de") é joanina.

Jo 18,23 Respondeu-lhe Jesus: Se falei errado, testemunha a respeito do errado; se, porém, falei certo, por que me bates?

Nesta altura, João menciona a passagem por Caifás, sem descrevê-la $(18,24)$ :

Jo 18,24 Anás, pois, enviou-o ligado para Caifás, o sumo sacerdote.

${ }^{\mathrm{Mc}}{ }^{14,53} \mathrm{E}$ conduziram Jesus ao sumo sacerdote, e juntaram-se todos os

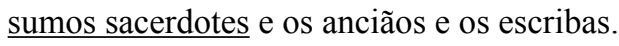

${ }^{\mathrm{Mt} 26,57}$ Eles, tendo preso Jesus, conduziram $\{-$ no $\}$ ao sumo sacerdote Caifás,

onde estavam reunidos os escribas e os anciãos.

Lc 22,54 Tendo-o aprisionado, porém, conduziram-no e o introduziram na casa do sumo sacerdote.

Nos sinópticos, o interrogatório perante Caifás oferece o quadro para as três negações de Pedro; em João, só para a segunda e a terceira (v. 25-27), pois ele já situou a primeira logo na entrada de Pedro no palácio, antes do interrogatório de Anás $(18,16 \mathrm{~s}$.), constituindo o pano de fundo para a menção de Jesus a seus ouvintes (Jo 18,21, cf. supra). Em todo o caso, as semelhanças são evidentes: 
Jo 18,15 (v. supra) Pedro, porém, estava junto à porta, fora. Saiu, pois, o outro discípulo, conhecido do sumo sacerdote, e disse à porteira, e conduziu Pedro para dentro. ${ }^{17} \mathrm{Diz}$, pois, a criada, a porteira, a Pedro: Não és também tu dentre os discípulos daquele homem? Disse ele: Não sou.

${ }^{\mathrm{Mc}}{ }^{14,65} \mathrm{E}$ Pedro estando no pátio, embaixo, vem uma das criadas do sumo sacerdote ${ }^{67} \mathrm{e}$, tendo visto Pedro que se aquecia, tendo-o fitado, diz: $\underline{\mathrm{Tu}}$ também estavas com o nazareno, Jesus! ${ }^{68}$ Ele negou, dizendo: Não sei nem entendo o que dizes! E saiu fora para a entrada do pátio.

Mt 26,69 Pedro, porém, estava sentado fora, no pátio, e aproximou-se dele uma criada dizendo: Tu também estavas com Jesus, o galileu! ${ }^{70}$ Ele, porém, negou diante de todos, dizendo: Não sei o que dizes.

Lc 22,55 Tendo-o visto, porém, sentado perto do fogo e, tendo-o fixado, uma criada disse-lhe: Este aqui também estava com ele! ${ }^{57}$ Ele, porém, negou, dizendo: Mulher, eu nem o conheço!

Na segunda negação, João é bastante semelhante aos sinópticos:

Jo 18,25 Simão Pedro estava aí e se aquecia (cf. Mc 14,67). Disseram, pois, a ele: Não és também tu dentre seus discípulos? Negou ele e disse: Não sou. ${ }^{\mathrm{Mc}}{ }^{14,69} \mathrm{E}$ a criada, vendo-o, começou novamente a dizer aos presentes (que): Este é um deles. ${ }^{70}$ Mas Pedro negou novamente.

Mt 26,71 Tendo ele, porém, saído para a entrada, uma outra o viu e disse aos ali: Este estava com Jesus, o nazareno. ${ }^{72} \mathrm{E}$ novamente negou, com juramento (que): Não conheço o homem!

${ }^{L c} 22,58$ E pouco depois, um outro, vendo-o, disse: Tu também és um deles. Mas Pedro respondeu: Não, homem, eu não.

Na terceira negação, João omite a letra da resposta de Pedro, mas realça o caráter dramático, identificando o servo como parente de Malco, a quem Pedro cortara a orelha $(18,10 \mathrm{c})$. O que tal testemunha ocular diz deve ser inegável, mas Pedro nega!

Jo 18,26 Diz um dentre os servos do sumo sacerdote, sendo parente daquele cuja orelha Pedro tinha cortado: Não te vi eu no jardim, com ele? De novo, pois, Pedro negou, e logo um galo cantou.

${ }^{\mathrm{Mc}} 14,70 \mathrm{~b} \mathrm{E}$, depois, de pouco, os presentes diziam a Pedro: Verdadeiramente és um deles, pois, és galileu. ${ }^{71}$ Ele começou então a praguejar e a jurar: Nem conheço esse homem que estais dizendo! ${ }^{72} \mathrm{E}$ logo, pela segunda vez, um galo cantou. 
Mt 26,73 Pouco depois, os que estavam ali aproximaram-se e disseram a Pedro: Verdadeiramente tu também és um deles, pois, até o teu modo de falar te denuncia. ${ }^{74}$ Então começou a praguejar e a jurar que não conhecia o homem! E logo um galo cantou.

${ }^{L c}{ }^{22,59} \mathrm{E}$ tendo passado como que uma hora, e um outro insistia, dizendo: Certamente, este aqui também estava com ele, pois, é galileu! E Pedro, porém, respondeu: ${ }^{60} \mathrm{Homem}$, nem sei o que dizes! E, imediatamente, ele ainda falando, um galo cantou.

Nesta primeira parte do processo notamos, principalmente, dois acentos "joaninos". A primeira parte (v. 1-11) ressalta a soberania de Jesus em sua parádōsis, que é antes uma autoentrega ${ }^{20}$ ativa do que o resultado passivo da traição de Judas, o qual perde seu papel, apesar de ser instrumento do diabo $(13,2)$. Não é o diabo que vence Jesus, o inverso é o caso (cf. 12,31; 14,30). Na segunda parte (v. 12-27), a inserção - lembrando os procedimentos midráxi$\cos ^{21}$ - do diálogo com Anás sugere que não é só Jesus que está sendo processado, mas seus discípulos e seu ensinamento. Significativamente, este momento é enquadrado pela negação do representante mor dos discípulos, o que para o leitor significa uma admoestação para dar o testemunho que Pedro não deu.

\subsection{O processo diante do mundo (do Império)}

A segunda secção do processo $(18,28-19,16 a)$ é o interrogatório de Jesus pelo procurador romano, Pilatos, que representa o "mundo" nos círculos concêntricos da oposição a Jesus e sua comunidade ${ }^{22}$.

De manhã cedo (v. 28), as autoridades judaicas conduzem Jesus ao governador romano, com a intenção de conseguir que ele condene Jesus à morte de cruz, que só a instância romana pode decretar.

Jo 18,28 Conduzem, pois, Jesus, de Caifás, ao pretório. Era, porém, cedo, e eles não entraram no pretório, para que não se contaminassem, mas comessem a páscoa.

\footnotetext{
${ }^{20}$ Cf. LÉON-DUFOUR, Leitura... IV, p. 23.

${ }^{21} \mathrm{O}$ midraxe, comentário explicativo ou paráfrase edificante de passagens da Escritura (judaica) (cf. NELIS, J.; HIRSCH, S. “Midrash”. In: DICIONÁRIO Enciclopédico da Bíblia. São Paulo; Loyola, 2013. pp. 892-893) muitas vezes cria cenas complementares para inserir uma interpretação. Num sentido amplo, são considerados midraxes, às vezes, livros inteiros, como, por exemplo, Rute (sobre o levirato, o resgate dos bens e a bisavô estrangeira de Davi).

${ }^{22}$ Cf. supra, nota 4.
} 


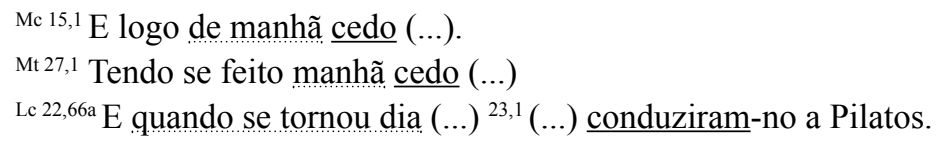

Aos dados tradicionais (Mc 15,1 par.) João acrescenta que eles não entram no pretório, pois devem ainda comer a refeição pascal ao anoitecer. Este detalhe é coerente com a cronologia joanina, que situa a morte de Jesus na véspera da Páscoa e não no próprio dia da Páscoa como os sinópticos. Pelo fato de os judeus não entrarem no pretório, a ação do processo romano se vê dividida em sete idas e voltas de Pilatos, para fora (para falar com os judeus) ou para dentro (para falar com Jesus) ${ }^{23}$.

Em Marcos e Mateus, os judeus não apresentam nenhuma razão para entregar Jesus a Pilatos. Mas, segundo a lógica, alguma razão deveria ter sido alegada. Por isso, Lucas e João preenchem essa lacuna cada um à sua maneira. Lc 23,2 narra que Pilatos foi informado acerca da ambição régia de Jesus: “(...) Achamos este pervertendo a nossa nação e impedindo dar tributos a César e dizendo ser ele mesmo o Ungido, o Rei”. Já João (18,29-31) mostra que os judeus cometem uma petitio principii: justificam a entrega a Pilatos alegando o que ainda deve ser provado: que Jesus é um malfeitor. Pilatos não se impressiona com isso e, desejando isentar-se, sugere que os judeus resolvam o caso. Mas estes querem ver aplicada a Jesus a pena capital que, segundo dizem, eles mesmos não podem aplicar.

Jo 18,29 Saiu, pois, Pilatos para fora em direção a eles e diz: Que acusação levais [contra] este homem? ${ }^{30}$ Responderam e disseram-lhe: Se não fosse este um malfeitor, não to entregaríamos. ${ }^{31}$ Disse-lhes, pois, Pilatos: Tomai-o vós e conforme vossa lei julgai-o. Disseram-lhe os judeus: A nós não é permitido matar ninguém.

Não é verdade que os judeus não poderiam matar. Anteriormente tentaram diversas vezes apedrejar Jesus $(8,59 ; 10,31 ; 11,8)$, e, provavelmente, a autoridade romana não teria intervindo se o tivessem feito! Mas o que eles querem é a condenação à morte de cruz, que só a autoridade romana podia decretar. Por isso, João acrescenta, no v. 32, um dos seus comentários característicos ${ }^{24}$.

\footnotetext{
${ }^{23}$ Cf. supra, nota 5 .

${ }^{24}$ Cf. VAN BELLE, G. Les parenthèses dans l'évangile de Jean: aperçu historique et classification; texte grec de Jean. Leuven: Peeters, 1985.
} 
Jo 18,32 Para que fosse cumprida a palavra de Jesus, que ele disse significando de que morte ele ia morrer.

Depois, Pilatos entra novamente para interrogar Jesus mesmo (v. 33):

Jo 18,33 Pilatos, pois, entrou de novo no pretório e chamou Jesus e disse-lhe:

Tu és o rei dos judeus?

Mc ${ }^{15,2} \mathrm{E}$ Pilatos lhe perguntou: Tu és o Rei dos Judeus?

Mt 27,11 Jesus, porém, foi posto diante do governador, e o governador lhe perguntou, dizendo: Tu és o rei dos judeus?

Lc 23,3 Pilatos, porém, lhe perguntou: Tu és o Rei dos Judeus?

Quando Jesus pergunta de onde Pilatos soube da acusação, este responde que o ficou sabendo através dos judeus e que ele nada tem a ver com isso, pois não é judeu (v. 34-35). A resposta distanciadora de Pilatos (que chama os judeus de etnia, éthnos, em vez de povo, laós) corresponde à tendência joanina de engrossar a responsabilidade das autoridades judaicas ${ }^{25}$.

Jo 18,34 Respondeu Jesus: Desde ti mesmo dizes isto, ou outros te falaram a respeito de mim? ${ }^{35}$ Respondeu Pilatos: Acaso sou eu judeu? Tua etnia e os sumos sacerdotes te entregaram a mim. Que fizeste?

Quanto à sua relação com o judaísmo, Jesus responde, ironicamente, no v. 36, que ele é tudo menos um rei dos judeus, pois, seus súditos lutariam contra os judeus para que não caísse nas mãos deles! Esta resposta, ausente de Marcos e marcada por traços joaninos ${ }^{26}$, mostra analogia com o texto redacional de Mateus que alude a uma intervenção dos anjos para livrar Jesus de seus acusadores.

Jo 18,36 Respondeu Jesus: Meu reino não é deste mundo. Se deste mundo fosse meu reino, meus súditos lutariam para que eu não fosse entregue aos judeus. Agora, porém, meu reino não é daqui.

Mt 26,53 Ou pensas que não posso invocar o meu Pai, e ele me disporá agora mais de doze legiões de anjos?

\footnotetext{
${ }^{25}$ Cf. BLINZLER, J. Der Prozess Jesu. Stuttgart: Katholisches Bibelwerk, 1951.

${ }^{26}$ João evita a terminologia judaica "reino de Deus", a não ser para dar início à "catequese a Nicodemos", Jo 3,3.5.
} 
Encontramos aqui as expressões joaninas "não deste mundo", "não daqui". Jesus não nega ser rei, mas, se ele exerce domínio, não é no sentido do messianismo judaico. Nos sinópticos, quando Pilatos pergunta a Jesus se ele é "rei dos judeus" (Mc 15,2a par.), Jesus responde "Tu o dizes" (Mc 15,2b par.). Segue-se um silêncio, que deixa aberto se Pilatos acertou (Jesus é o Messias) ou se enganou (pois Jesus é o "messias diferente"). Em João, a inserção dos vv. 34-36 exclui que Jesus seja o messias judaico, mas não que ele seja rei. Assim, em 18,37, a pergunta se torna retórica, supondo resposta positiva. Compare-se:

${ }^{\text {Mc } 15,2 b}$ Ele, respondendo, disse: $\underline{\text { Tu o dizes. }}$ (= Mt 27,11 c\|l Lc 23,3b)

Jo 18,37ab Disse-lhe, pois, Pilatos: Então não és rei? Respondeu Jesus: $\underline{\mathrm{Tu}}$ dizes que sou rei.

Diferentemente de Mc 15,2, João não acrescenta ao termo "rei" a especificação "dos judeus". Por isso, Jesus pode responder positivamente: "Tu dizes que sou rei”. E logo explica em que sentido:

Jo $18,37 \mathrm{C}$ Eu nasci para isto, e para isto vim ao mundo: para que testemunhe da verdade. Todo o que é da verdade escuta a minha voz. ${ }^{38 a}$ Diz-lhe Pilatos:

Que é: verdade?

O estilo e o teor da explicação de Jesus são totalmente joaninos: vir ao mundo, testemunhar, verdade, escutar a voz de Jesus. A resposta de Pilatos, "Que é a verdade?", chegou a ser interpretada como sinal de busca da verdade. Mas o fato de entregar, sem fundamento e por medo $(19,12.15)$, Jesus à crucificação revela o cinismo de Pilatos: "Verdade, que é isso?". Pilatos não é "da verdade".

No v. 38b, Pilatos sai novamente para dizer que não encontra motivo de condenação. Nos sinópticos, depois da escolha entre Jesus e Barrabás, Pilatos pergunta qual foi o mal que Jesus fez. João, porém, coloca a afirmação da inocência antes da escolha, a qual, por isso, vira uma farsa ${ }^{27}$.

Jo $18,38 b \mathrm{E}$ tendo dito isto, de novo saiu em direção aos judeus e lhes diz: Eu não encontro nele nenhum motivo de condenação. ${ }^{39}$ Porém, é nosso costume (para) que vos solte alguém na Páscoa. Desejais, pois, que vos

${ }^{27}$ Ainda mais porque opõe à inocência de Jesus a acusação de que Barrabás era bandido, lêstēs. 
solte o rei dos Judeus? ${ }^{40}$ Gritavam, pois, de novo dizendo: Não este, mas Barrabás. Barrabás era um bandido.

Mc 15,5 Segundo a festa, soltava para eles um preso que solicitassem. ${ }^{7}$ Havia, porém, o chamado Barrabás, preso com os amotinados, os quais, num motim, cometeram um homicídio. ${ }^{8} \mathrm{E}$, tendo subido, a turba começou a pedir assim como ele \{costumava\} fazer para eles. Pilatos, porém, respondeu-lhes, dizendo: Quereis que vos solte o Rei dos Judeus? (...) ${ }^{12}$ Ele dizia-lhes: Que portanto [quereis] que eu faça com o [que chamais] $\underline{\text { Rei dos Judeus? }}{ }^{13}$ Eles novamente gritaram: Crucifica-o! ${ }^{14}$ Pilatos, porém, lhes dizia: Que mal, pois, ele fez? Eles, porém, gritaram mais ainda: Crucifica-o!

Mt 27,15 Segundo a festa, o governador costumava soltar para a turba um preso que quisessem. ${ }^{15}$ Tinham então um preso famoso, chamado [Jesus] Barrabás. ${ }^{17}$ Estando eles reunidos, Pilatos lhes disse: Qual quereis que vos solte: [Jesus] Barrabás ou Jesus chamado o Ungido? (...) ${ }^{21}$ Respondendo, porém, o governador disse-lhes: Qual dos dois quereis que eu vos solte? Eles disseram: Barrabás. ${ }^{22}$ Pilatos lhes diz: Que, portanto, farei com Jesus, chamado o Ungido? Todos dizem: Seja crucificado! ${ }^{23}$ Ele disse: Que mal, pois, ele fez? Eles, porém, gritavam mais ainda: Seja crucificado!

Lc 23,18 Toda a multidão, porém, gritava: Leva-o! Solta-nos Barrabás! ${ }^{19} \mathrm{O}$ qual tinha sido lançado à prisão por causa de um motim na cidade e por homicídio. ${ }^{20}$ Pilatos dirigiu a voz à turba querendo soltar Jesus. ${ }^{21}$ Eles, porém, vociferavam: Crucifica, crucifica-o! ${ }^{22} \mathrm{E}$ Pilatos disse-lhes pela terceira vez: Que mal, pois, fez este? Não encontrei nele nada condenável de morte. Portanto, depois de o castigar, vou soltá-lo. ${ }^{23}$ Eles porém insistiam com vozes fortes pedindo que ele fosse crucificado, e suas vozes prevaleceram.

Na expressão "eu não encontro nele nenhum motivo de condenação", Jo 18,38 b demonstra certa proximidade com Lc 23,22b. Segundo Lucas, a flagelação devia servir apenas para que Pilatos desse satisfação aos acusadores, antes de soltar Jesus - intenção que ficou frustrada (cf. Lc 23,23). Mc 15,15 e Mt 27,24-26 desconhecem aqui a intenção de soltar Jesus; segundo a descrição deles, Pilatos parece mandar açoitar e escarnecer Jesus como prelúdio da crucificação. Lucas não descreve o escárnio quando menciona a entrega de Jesus para a execução, mas tem uma cena semelhante quando Jesus é reconduzido de Herodes a Pilatos (Lc 23,11). Em Jo 19,1-3, a cena torna-se central ${ }^{28}$ :

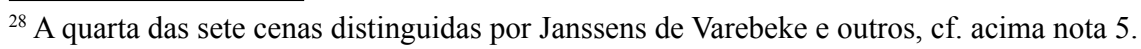


Jo 19,1 Então, pois, Pilatos tomou Jesus e açoitou-o. ${ }^{2} \mathrm{E}$ os soldados, tendo trançado uma coroa de espinhos, a puseram na cabeça dele e o envolveram num manto purpúreo. ${ }^{3}$ E iam até ele e diziam: Salve, rei dos judeus. E davam-lhe bofetadas.

Mc $15,15 \mathrm{~b}$ (...) e, tendo açoitado Jesus, entregou-o para ser crucificado. ${ }^{17} \mathrm{E}$ vestiram-no com púrpura, e puseram nele, tendo $\{-\mathrm{a}\}$ trançado, uma coroa de espinhos. ${ }^{18} \mathrm{E}$ começaram a saudá-lo: Salve, rei dos judeus! ${ }^{19} \mathrm{E}$ batiam na cabeça dele com um junco, e cuspiam nele e, dobrando os joelhos, se prostravam diante dele.

Mt 27,26b (...) tendo, porém, açoitado Jesus, entregou-o para ser crucificado. ${ }^{28} \mathrm{E}$ tendo-o despido, puseram nele uma capa escarlate; ${ }^{29} \mathrm{e}$ tendo trançado uma coroa de espinhos, a puseram na cabeça dele, e um junco em sua mão direita. E ajoelhados diante dele, zombavam dele, dizendo: $\underline{\text { Salve, rei dos }}$ judeus! ${ }^{30} \mathrm{E}$ cuspindo nele, pegaram o junco e batiam na cabeça dele.

${ }_{\mathrm{Lc} 23,25 \mathrm{~b}}(\ldots)$ entregou, porém, Jesus à vontade deles.

Em João encontramos a declaração de inocência antes $(18,38 b)$ e depois da flagelação e do escárnio $(19,4)$. Enquanto em Mateus e Marcos, depois do escárnio, Jesus é novamente vestido com suas próprias vestes, João aproveita esse tema para criar uma nova cena, em que Jesus é apresentado ao povo vestido como rei de zombaria, como na cena redacional de Lc 23,11 perante Herodes.

Jo 19,4 E Pilatos saiu de novo para fora e disse-lhes: Eu vo-lo conduzo para fora, para que saibais que não encontro nele nenhum motivo de condenação. ${ }^{5}$ Saiu, pois, Jesus para fora, levando a coroa espinhosa e o manto de púrpura. E \{Pilatos\} dizia-lhes: Eis o homem.

Lc 23,11 Herodes [também] com seus soldados, tendo-o desprezado e tendo-o, por zombaria, envolvido com uma roupa vistosa, mandou-o de volta a Pilatos.

Qual é o significado desta cena? Provavelmente não a apresentação do ser humano universal, como às vezes tem sido proposto, pois as vestes e a coroa não sugerem a humanidade universal, e sim, o "rei dos judeus", ridicularizado: "Ei-lo, o vosso rei que me entregastes!". Trata-se de uma última e irônica tentativa de Pilatos para, declarando-o inocente, poder soltá-lo. Mas o resultado será negativo (cf. Mc 15,14\|Mt 17,23\|Lc 23,22s.).

Jo 19,6 Quando, pois, os sumos sacerdotes e os súditos o viram, gritaram dizendo: Crucifica, crucifica. Diz-lhes Pilatos: Tomai-o, vós, e crucificai, pois eu não encontro nele motivo de condenação. 
Quando, assim, Pilatos declara pela terceira vez a inocência de Jesus, os judeus insistem na condenação, agora não mais com base em alguma acusação sancionada pela lei romana, mas em base de sua própria lei: a blasfêmia que eles veem no fato de Jesus se proclamar filho de Deus ${ }^{29}$.

${ }^{7}$ Disseram-lhe os judeus: Nós temos uma lei e conforme a lei é preciso que morra, porque se fez filho de Deus.

Pilatos, assustado com o termo "Filho de Deus", entra novamente para interrogar Jesus (v. 8-11). Ao fator político (de Jesus ter-se declarado rei dos judeus) acresce o fator religioso. João não explica se Pilatos receia algo "sobrenatural" ou o fanatismo religioso dos judeus, mas usa o tema para contrastar a origem divina da missão de Jesus com a relatividade do poder de Pilatos.

${ }^{8}$ Quando, pois, ouviu Pilatos esta palavra, mais ainda teve medo, ${ }^{9} \mathrm{e}$ entrou no pretório de novo e diz a Jesus: De onde és tu? Jesus, porém, não deu resposta. ${ }^{10}$ Diz-lhe, pois, Pilatos: Não falas a mim? Não sabes que tenho poder de te soltar e tenho poder de te crucificar? ${ }^{11}$ Respondeu [lhe] Jesus: Não terias poder nenhum sobre mim, se não te fosse dado do alto. Por isso, o que me entregou a ti tem pecado maior.

$\mathrm{Na}$ frase $11 \mathrm{~b}$ Jesus acuse aquele que o entrega de "ter pecado maior"30. Ora, rastreando o termo "entregar", lembramos que, "quem entregou" Jesus a Pilatos foram os judeus; quem o entregou aos judeus foi Judas, e quem manipulou Judas foi o diabo, o príncipe deste mundo: eis o verdadeiro culpado ("tem pecado maior"), o antagonista principal no nível profundo.

Nos vv. 12-15, Pilatos, embora querendo soltar Jesus, é obrigado a decidir o contrário:

${ }^{12}$ Desde então Pilatos procurava soltá-lo. Os judeus, porém, gritavam dizendo: Se a este soltares, não és amigo de César. Todo o que se faz rei contradiz o César. ${ }^{13}$ Pilatos, pois, tendo ouvido estas palavras, conduziu Jesus para fora e sentou-se na cátedra, no lugar chamado Pavimento, em hebraico Gábata. ${ }^{14}$ Era dia de preparação da Páscoa; era quase a hora

\footnotetext{
${ }^{29}$ Embora já tenha ficado claro que Jesus não se arroga igualdade a Deus, como denunciam os judeus $(5,18 ; 10,33)$, pois ele é Filho, unido ao Pai em sua obra $(5,19 ; 10,35-36)$. Filho não é pai, e o Pai é maior que o Filho $(14,28)$.

${ }^{30}$ Semitismo para: a culpa principal.
} 
sexta. E diz aos judeus: Eis vosso rei. ${ }^{15}$ Gritavam, pois, eles: Leva, leva, crucifica-o. Diz-lhes Pilatos: Crucificarei vosso rei? Responderam os sumos-sacerdotes: Não temos rei se não o César.

Quando os judeus ameaçam Pilatos com chantagem junto a Cesar, ele bate o martelo e toma lugar na cátedra ${ }^{31}$, ironizando que ele terá de condenar o rei dos judeus, o "vosso rei" (v. 14). A nota cronológica, em parêntese, no v. 14a, lembra que é véspera da Páscoa, quando são imolados os cordeiros pascais. Jesus é assim associado ao cordeiro pascal, como será confirmado pela citação de S1 34,21 em Jo 19,36: "Não serão quebrados os seus ossos". Jesus, o cordeiro que tira o pecado do mundo (Jo 1,29), morre na hora do cordeiro pascal. Entretanto, os judeus respondem que eles não têm outro rei senão César, renegando assim o seu estatuto de povo de Deus e sua esperança messiânica.

Segue-se, no v. 16a, o fim do processo, com uma lembrança literal dos sinópticos:

${ }^{16 a}$ Então, pois, entregou-o a eles para ser crucificado.

$\mathrm{Mc} 15,15 \mathrm{~b}=\mathrm{Mt} 27,26 \mathrm{~b}$ (...) entregou-o (...) para ser crucificado.

Lc 23,25b (...) entregou, porém, Jesus à vontade deles.

"Entregou-o a eles" significa, gramaticalmente, que Pilatos entregou Jesus aos acusadores ${ }^{32}$ : tendo renegado suas prerrogativas nacionais e religiosas, eles são reduzidos a meros súditos romanos e, nesta condição, recebem Jesus para levá-lo à crucificação, que enquanto autoridade judaica eles não podiam decretar. No tempo da narração, depois da destruição do Templo, quando o judaísmo rabínico nascente busca a hegemonia e exclui os cristãos, essa desqualificação tem peso aos olhos do leitor: como podem essas "autoridades" querer ligar os seguidores de Jesus às suas sinagogas?

\section{Conclusão}

No fim deste estudo, ainda elementar e aguardando análise mais aprofundada, podemos esboçar algumas conclusões provisórias.

\footnotetext{
${ }^{31}$ A interpretação "fê-lo sentar-se" (cf. I. de la Potterie) não se sustenta nem gramatical, nem literariamente. Cf. BEUTLER, Evangelho..., pp. 431-432.

32 Gramaticalmente, autoîs se refere aos personagens mencionados imediatamente antes: as autoridades judaicas. BEUTLER, Evangelho..., p. 433: "Pilatos entrega Jesus aos 'judeus' para que seja crucificado pela justiça e pela força militar romana".
} 
O processo de Jesus em João segue substancialmente o modelo e o vocabulário dos sinópticos. Além do esquema sinóptico geral (essencialmente o de Marcos), há semelhanças particulares com Mateus e Lucas, que, se não provêm de empréstimo textual, sugerem que o autor joanino captou ecos dos relatos lucano e mateano, talvez na oralidade pós-sinóptica.

João, porém, desenha com traços mais fortes do que os sinópticos os dois círculos diante dos quais os cristãos se encontram em processo: o círculo interior, "os judeus", e o círculo abrangente, "o mundo". Em vista do círculo interior, João abre uma janela na narrativa sinóptica, ao inserir o interrogatório de Anás, que visa à situação da comunidade depois da ruptura com a sinagoga, quando é preciso dar testemunho a respeito dos discípulos e do ensinamento (Jo 18,19). Em vista do círculo do mundo, João abre outra janela, ao ampliar o interrogatório diante de Pilatos, para mostrar que não se deve esperar nada do poder deste mundo, cinicamente atrelado ao príncipe deste mundo, o "verdadeiro culpado". O diálogo com Pilatos mostra, ainda, qual é o verdadeiro reino daquele que está sendo julgado pela suposta pretensão de ser rei dos judeus: o domínio da "verdade" que ele testemunha.

Também os outros traços que distinguem a narrativa joanina da sinóptica correspondem à intenção própria do autor e ao efeito que o texto quer produzir no leitor; assim, por exemplo, a potencialização da soberania de Jesus, no texto inteiro, desde a cena no jardim até o diálogo com Pilatos. Serve à pragmática do texto também a presença discreta do "outro discípulo", que contracena com Simão Pedro, o covarde. Diferentemente de Pedro, que se aquece na companhia dos guardas do sumo sacerdote, o Discípulo Amado estará onde está Jesus (cf. 12,26), ao pé da cruz $(19,26)$, para ser a testemunha exímia da consumação de sua obra $(19,35)$.

Assim, a pragmática do texto joanino aponta para uma situação em que o leitor/ouvinte é instado a enfrentar a perseguição e a dar testemunho da "verdade", que é o verdadeiro reino ou domínio de Deus, evocado por Jesus no diálogo com Pilatos.

\section{Referências bibliográficas}

ALAND, K. Synopsis quattuor Evangeliorum: locis parallelis evangeliorum apocryphorum et patrum adhibitis. 9. erneut revid. Aufl. Stuttgart: Württembergische Bibelanstalt, 1976.

BEUTLER, J. Evangelho segundo João: comentário. São Paulo: Loyola, 2015. 
BLINZLER, J. Der Prozess Jesu. Stuttgart: Katholisches Bibelwerk, 1951.

COLSON, J. L'énigme do disciple que Jésus aimait. Paris: Beauchesne, 1969.

DAUER, A. Die Passionsgeschichte im Johannesevangelium: Eine traditionsgeschichtliche und theologische Untersuchung zu Joh. 18,1-19,30. München: Kösel, 1972.

JANSSENS DE VAREBEKE, A. "La structure des scènes du récit de la Passion en Joh., 18-19. Recherches sur les procédés de composition et de rédaction du Quatrième Évangile". Ephemerides Theologicae Lovanienses 38 (1962), pp. 504-522.

KONINGS, J. Evangelho segundo João: amor e fidelidade. 2. ed. São Paulo: Loyola, 2005.

KONINGS, J. Sinopse dos evangelhos de Mateus, Marcos e Lucas e da "Fonte Q’. São Paulo: Loyola, 2005.

LÉON-DUFOUR, X. Leitura do Evangelho segundo João (IV). São Paulo: Loyola, 1998.

NEIRYNCK, F. “"The Other Disciple' in Jn 18,15-16”. Ephemerides Theologicae Lovanienses 51 (1975), pp. 113-141.

NELIS, J.; HIRSCH, S. "Midrash”. In: DICIONÁRIO Enciclopédico da Bíblia. São Paulo: Loyola, 2013, pp. 892-893.

SABBE, M. "The Arrest of Jesus in Jn 18,1-11 and Its Relation to the Synoptic Gospels. A Critical Evaluation of A. Dauers Hypothesis". In: SABBE, M. Studia Neotestamentica: Collected Essays. Leuven: Peeters, 1991.

VAN BELLE, G. Les parenthèses dans l'évangile de Jean: aperçu historique et classification; texte grec de Jean. Leuven: Peeters, 1985.

ZUMSTEIN, J. "Der Prozess Jesu vor Pilatus. Ein Beispiel Johanneischer Eschatologie". In: ZUMSTEIN, J. Kreative Erinnerung. Relecture und Auslegung im Johannesevangelium. Zürich: Theologischer Verlag, 2004, pp. 253-273.

ZUMSTEIN, J. L'évangile selon saint Jean (13-21). Genéve: Labor et fides, 2007. 
Doutor em Teologia pela Katholieke Universiteit Leuven (Bélgica) Professor de Novo Testamento na Faculdade Jesuíta de Filosofia e Teologia (FAJE) Belo Horizonte / MG - Brasil E-mail: konings@faculdadejesuita.edu.br

Recebido em: 29/08/16 Aprovado em: 26/09/16 